\title{
Carbon flux to woody tissues in a beech/spruce forest during summer and in response to chronic $\mathrm{O}_{3}$ exposure
}

\author{
W. Ritter ${ }^{1}$, C. P. Andersen ${ }^{2}$, R. Matyssek ${ }^{1}$, and T. E. E. Grams ${ }^{1}$ \\ ${ }^{1}$ Ecophysiology of Plants, Department of Ecology and Ecosystem Management, Technische Universität München, \\ Hans-Carl-von-Carlowitz-Platz 2, 85354 Freising, Germany \\ ${ }^{2}$ US Environmental Protection Agency, Western Ecology Division, 200 SW 35th St., Corvallis, OR 97333, USA
}

We would like to dedicate this work to Prof. Dr. Ulrich Lïttge on the occasion of his 75 th birthday.

Received: 27 February 2011 - Published in Biogeosciences Discuss.: 26 April 2011

Revised: 19 September 2011 - Accepted: 25 September 2011 - Published: 3 November 2011

\begin{abstract}
The present study compares the dynamics in carbon (C) allocation of adult deciduous beech (Fagus sylvatica) and evergreen spruce (Picea abies) during summer and in response to seven-year-long exposure with twice-ambient ozone $\left(\mathrm{O}_{3}\right)$ concentrations $\left(2 \times \mathrm{O}_{3}\right)$. Focus was on the respiratory turn-over and translocation of recent photosynthates at various positions along the stems, coarse roots and soils. The hypotheses tested were that (1) $2 \times \mathrm{O}_{3}$ decreases the allocation of recent photosynthates to $\mathrm{CO}_{2}$ efflux of stems and coarse roots of adult trees, and that (2) according to their different $\mathrm{O}_{3}$ sensitivities this effect is stronger in beech than in spruce.

Labeling of whole tree canopies was applied by releasing ${ }^{13} \mathrm{C}$ depleted $\mathrm{CO}_{2}\left(\delta^{13} \mathrm{C}\right.$ of $-46.9 \%$ ) using a free-air stable carbon isotope approach. Canopy air $\delta^{13} \mathrm{C}$ was reduced for about 2.5 weeks by ca. $8 \%$ in beech and $6 \%$ in spruce while the increase in $\mathrm{CO}_{2}$ concentration was limited to about $110 \mu \mathrm{l}^{-1}$ and $80 \mu \mathrm{l}^{-1}$, respectively. At the end of the labeling period, $\delta^{13} \mathrm{C}$ of stem $\mathrm{CO}_{2}$ efflux and phloem sugars was reduced to a similar extend by ca. 3-4\%o (beech) and ca. 2$3 \%$ (spruce). The fraction of labeled $\mathrm{C}\left(f_{\mathrm{E} \text {,new }}\right)$ in stem $\mathrm{CO}_{2}$ efflux amounted to 0.3 to 0.4 , indicating slow $\mathrm{C}$ turnover of the respiratory supply system in both species.

Elevated $\mathrm{O}_{3}$ slightly stimulated the allocation of recently fixed photosynthates to stem and coarse root respiration in spruce (rejection of hypothesis I for spruce), but resulted in a significant reduction in $\mathrm{C}$ flux in beech (acceptance of hypotheses I and II). The distinct decrease in $\mathrm{C}$ allocation to
\end{abstract}

Correspondence to: T. E. E. Grams (grams@tum.de) beech stems indicates the potential of chronic $\mathrm{O}_{3}$ stress to substantially mitigate the $\mathrm{C}$ sink strength of trees on the longterm scale.

\section{Introduction}

Tropospheric ozone $\left(\mathrm{O}_{3}\right)$ is a major component of global climate change (IPCC, 2007), mitigating the carbon (C) sink strength of forest trees and ecosystem productivity (Sitch et al., 2007; Matyssek et al., 2010b). Along with increased emissions of anthropogenic precursors, in particular nitrogen oxides, tropospheric $\mathrm{O}_{3}$ concentrations are predicted to rise over Central Europe and at the global scale (Fowler et al., 1999, 2008; Prather et al., 2001). Elevated $\mathrm{O}_{3}$ concentrations are known to negatively affect the metabolism and growth of a wide range of tree species, including deciduous European beech (Fagus sylvatica) and evergreen Norway spruce (Picea abies; Matyssek et al., 2010a, b; Wieser et al., 2002; Nunn et al., 2006). Photosynthetic decline, impaired phloem loading, and increased $\mathrm{C}$ demand for repair have all been observed in response to ozone exposure. Detoxification may curtail the tree-internal assimilate flux to stems, roots and soils in response to $\mathrm{O}_{3}$ (Andersen, 2003; Matyssek and Sandermann, 2003; Wieser and Matyssek, 2007).

Since the flux of current photosynthates is considered an important driver of woody tissue and soil respiration in forests (Ryan et al., 1996; Högberg et al., 2001), limited C availability caused by $\mathrm{O}_{3}$ stress may affect the respiratory activity and growth of stems and total belowground $\mathrm{C}$ allocation (Matyssek et al., 1992; Günthardt-Goerg et al., 1993; Coleman et al., 1996; Spence et al., 1990). As a result, root

Published by Copernicus Publications on behalf of the European Geosciences Union. 
biomass and sugar concentrations may be reduced (Grulke et al., 1998, 2001). Highlighting the phototoxic potential of $\mathrm{O}_{3}$ to Central-European forests, Pretzsch et al. (2010) reported a $40 \%$ decrease in stem growth of adult beech upon eight years of twice-ambient $\mathrm{O}_{3}$ exposure, whereas spruce showed no significant growth response. Likewise, in phytotron experiments on juvenile beech, reduced allocation of recent photosynthates to stems was identified as the mechanistic basis for reduced stem growth and competitiveness in response to $2 \times \mathrm{O}_{3}$ (Kozovits et al., 2005a, b; Ritter et al., 2011).

In the present paper, we investigate dynamics in $\mathrm{C}$ allocation of adult trees in response to chronically elevated $\mathrm{O}_{3}$ concentrations. Clarification is particularly needed for respiratory $\mathrm{C}$ fluxes of woody tissues. We compare the allocation of recent photosynthates to the respiratory turn-over in stems, coarse roots and soils in adult beech and spruce in a naturally grown forest.

In accordance with their contrasting $\mathrm{O}_{3}$ sensitivity, we hypothesized that (1) $2 \times \mathrm{O}_{3}$ decreases allocation of recent photosynthates to stem and coarse root $\mathrm{CO}_{2}$ efflux of adult trees and (2) that this effect is stronger in beech than in spruce. To this end, we took advantage of a unique free-air $\mathrm{O}_{3}$ fumigation experiment employed in a mixed forest with adult beech and spruce trees (Matyssek et al., 2010b). Stable carbon isotope labeling was performed on these trees using the isoFACE exposure system (Grams et al., 2011). In view of hypothesis evaluation, focus was on translocation of recent photosynthates and $\mathrm{CO}_{2}$ efflux at various positions along the stems and coarse roots.

\section{Material and methods}

\subsection{Experimental design}

The study was carried out during August/early September 2006 in a 60 to 70-year-old mixed beech/spruce stand at "Kranzberger Forst" in southern Bavaria, near Freising, Germany (elevation $485 \mathrm{~m}$ a.s.1., $48^{\circ} 25^{\prime} \mathrm{N}, 1^{\circ} 39^{\prime} \mathrm{E}$; Pretzsch et al., 1998). Trees of European beech (Fagus sylvatica [L.]) and Norway spruce (Picea abies [L.] Karst.), about 25 to $28 \mathrm{~m}$ high, were exposed to either unchanged ambient $(1 \times)$ or experimentally increased twice-ambient $(2 \times) \mathrm{O}_{3}$ concentrations. The $2 \times \mathrm{O}_{3}$ regime had experimentally been enhanced since 2000, using a free-air $\mathrm{O}_{3}$ exposure system (Werner and Fabian, 2002; Karnosky et al., 2005). To prevent risk of acute $\mathrm{O}_{3}$ injury in the $2 \times \mathrm{O}_{3}$ regime, maximum $\mathrm{O}_{3}$ concentrations were restricted to $<150 \mathrm{nl}^{-1}$ (cf. Matyssek and Sandermann, 2003). The exclusion of untypically high $\mathrm{O}_{3}$ peaks resulted in a chronically enhanced $2 \times \mathrm{O}_{3}$ regime with a higher frequency of $\mathrm{O}_{3}$ levels that currently occur sporadically at the site, by this, simulating the widely observed trend of currently increasing $\mathrm{O}_{3}$ background concentrations (Fowler et al., 2008; Sitch et al., 2007; Vingarzan, 2004). The forest grew on luvisol derived from loess over tertiary sediments with high nutrition and water supply. Long-term mean (1970-2000) annual air temperature and rainfall were $7.8^{\circ} \mathrm{C}$ and $786 \mathrm{~mm}$, respectively (monitored by Deutscher Wetterdienst at climate station "Weihenstephan", at $4 \mathrm{~km}$ distance from the research site; DWD Offenbach, Germany; Matyssek et al., 2007). Scaffoldings and a canopy crane provided access to the tree canopies.

\subsection{Climate conditions and stable carbon isotope labeling}

After a warm and dry period in July 2006 air temperature decreased during the labeling experiments in August and September (Table 1, Fig. 1). Correspondingly, highest $\mathrm{O}_{3}$ concentrations occurred during July, and AOT40 (i.e. accumulated $\mathrm{O}_{3}$ concentrations above a threshold of $40 \mathrm{nll}^{-1}$ ) exceeded the critical level of $5 \mu \mathrm{O}_{3} \mathrm{l}^{-1} \mathrm{~h}$ under the $1 \times \mathrm{O}_{3}$ regime already in May (LRTAP Mapping Manual, 2004; Nunn et al., 2005a). $\mathrm{O}_{3}$ concentrations in the $2 \times \mathrm{O}_{3}$ treatment were enhanced by a factor of 1.6 because of the maximum level of $150 \mu 1^{-1}$ (see above). Continuous stable carbon isotope labeling was performed from 18 August through 5 September and 26 August through 12 September in beech and spruce, respectively, using a free-air stable carbon isotope exposure system ("isoFACE", for details see Grams et al., 2011). In brief, from 07:00 through 19:00 LT, ${ }^{13} \mathrm{C}$-depleted $\mathrm{CO}_{2}\left(\delta^{13} \mathrm{C}\right.$ of ca. $-46.9 \%$ ) was homogenously released into the canopy of three study trees in each $\mathrm{O}_{3}$ regime and species (total of 12 trees) by means of micro-porous tubes. During label exposure, $\mathrm{O}_{3}$ concentrations (means $\pm \mathrm{SE}$ ) were $29.7 \pm 6.9\left(1 \times \mathrm{O}_{3}\right)$ and $49.3 \pm 11.9 \mathrm{nl}^{-1}\left(2 \times \mathrm{O}_{3}\right.$; Fig. 1a). Photosynthetic photon flux density (PPFD) was moderate due to frequently overcast sky and occasional precipitation (48 and $32 \mathrm{~mm}$ during beech and spruce labeling period, respectively, Fig. 1b).

\subsection{Isotope-ratio mass spectrometry (IRMS)}

Gas samples were analyzed for $\delta^{13} \mathrm{C}$ within $48 \mathrm{~h}$ by IRMS (GVI-Isoprime, Elementar, Hanau, Germany) coupled to a gas autosampler (Gilson 221 XL, Gilson Inc. Middleton, USA). Dried plant material was analyzed in a combined elemental analyzer (EA3000, Euro Vector, Milan, Italy) and IRMS. Carbon isotope ratios are expressed in delta notation $\left(\delta^{13} \mathrm{C}\right)$ using the Vienna PeeDee Belemnite (VPDB) as a standard. For gaseous and solid samples, the iterated measurements of a laboratory working standard showed a precision of $\delta^{13} \mathrm{C}<0.1 \%$ ( $\left.\mathrm{SD}, n=10\right)$.

\subsection{Assessment of $\mathrm{CO}_{2}$ concentration and $\delta^{13} \mathrm{C}$ of canopy air}

$\mathrm{CO}_{2}$ concentration $\left(\left[\mathrm{CO}_{2}\right]\right.$ ) and $\mathrm{C}$ isotope composition $\left(\delta^{13} \mathrm{C}\right)$ of canopy air were monitored at two heights (i.e. at 1 and $5 \mathrm{~m}$ underneath the upper canopy edge, corresponding 
Table 1. Weather conditions and $\mathrm{O}_{3}$ levels at the study site "Kranzberger Forst" during the growing season of 2006. Monthly sum of precipitation and average of daytime photosynthetic photon flux density (PPFD), relative air humidity $(\mathrm{RH})$, air temperature $\left(T_{\text {air }}\right)$, vapor pressure deficit (VPD) and soil moisture ( \pm SE, $n=30$ to 31 ). Ozone levels as monthly means $\pm \operatorname{SE}(n=30$ to 31 ), AOT40 (i.e. accumulated $\mathrm{O}_{3}$ concentrations above a threshold of $40 \mathrm{nl}^{-1}$ ) and SUM0 (i.e. daily sum of hourly $\mathrm{O}_{3}$ concentrations).

\begin{tabular}{|c|c|c|c|c|c|c|}
\hline 2006 & May & June & July & August & September & October \\
\hline $\operatorname{PPFD}\left[\mu \mathrm{mol} \mathrm{m}{ }^{-2} \mathrm{~s}^{-1}\right]$ & $458.6 \pm 29.7$ & $565.3 \pm 28.7$ & $601.1 \pm 23.7$ & $345.6 \pm 20.4$ & $363.4 \pm 23.1$ & $217.7 \pm 12.4$ \\
\hline RH [\%] & $69.8 \pm 2.2$ & $68.5 \pm 2.0$ & $66.2 \pm 2.3$ & $80.7 \pm 1.2$ & $77.7 \pm 1.4$ & $80.7 \pm 0.6$ \\
\hline$T_{\text {air }}\left[{ }^{\circ} \mathrm{C}\right]$ & $12.8 \pm 0.5$ & $16.9 \pm 0.9$ & $21.4 \pm 0.4$ & $14.5 \pm 0.4$ & $16.2 \pm 0.4$ & $11.5 \pm 0.5$ \\
\hline Rainfall $[\mathrm{mm}]$ & $82.4 \pm 0.7$ & $92.1 \pm 1.3$ & $29.0 \pm 0.4$ & $113.8 \pm 0.9$ & $12.6 \pm 0.3$ & $35.6 \pm 0.8$ \\
\hline VPD $[\mathrm{hPa}]$ & $5.1 \pm 0.5$ & $7.1 \pm 0.7$ & $10.2 \pm 0.8$ & $3.5 \pm 0.4$ & $4.7 \pm 0.4$ & $2.8 \pm 0.2$ \\
\hline \multicolumn{7}{|l|}{ Soil moisture [vol \%] at } \\
\hline $5 \mathrm{~cm}$ depth & $30.7 \pm 0.2$ & $28.4 \pm 0.5$ & $22.5 \pm 0.8$ & $21.4 \pm 0.4$ & $17.5 \pm 0.2$ & $17.1 \pm 0.1$ \\
\hline $30 \mathrm{~cm}$ depth & $34.1 \pm 0.2$ & $32.3 \pm 0.4$ & $27.9 \pm 0.4$ & $26.1 \pm 0.1$ & $24.7 \pm 0.1$ & $25.4 \pm 0.1$ \\
\hline $70-140 \mathrm{~cm}$ depth & $29.6 \pm 0.2$ & $27.9 \pm 0.2$ & $25.0 \pm 0.3$ & $22.9 \pm 0.1$ & $21.5 \pm 0.1$ & $21.7 \pm 0.1$ \\
\hline $1 \times \mathrm{O}_{3}$ concentration $\left[\mathrm{nll}^{-1}\right]$ & $47.5 \pm 2.8$ & $45.3 \pm 1.8$ & $53.0 \pm 1.7$ & $29.5 \pm 1.5$ & $26.0 \pm 1.6$ & $15.5 \pm 1.4$ \\
\hline $2 \times \mathrm{O}_{3}$ concentration $\left[\mathrm{nl}^{-1}\right]$ & $67.0 \pm 3.3$ & $72.6 \pm 3.7$ & $86.2 \pm 3.6$ & $47.9 \pm 2.3$ & $44.1 \pm 2.9$ & $23.5 \pm 2.2$ \\
\hline AOT40 $1 \times \mathrm{O}_{3}\left[\mu \mathrm{l} 1^{-1} \mathrm{~h}\right]$ & 5.7 & 4.7 & 7.4 & 0.8 & 0.6 & 0.0 \\
\hline AOT40 $2 \times \mathrm{O}_{3}\left[\mu 11^{-1} \mathrm{~h}\right]$ & 13.0 & 17.1 & 23.2 & 6.7 & 5.1 & 1.0 \\
\hline SUM0 $1 \times \mathrm{O}_{3}\left[\mu 11^{-1} \mathrm{~h}\right]$ & 33.0 & 30.1 & 36.8 & 21.6 & 18.6 & 8.7 \\
\hline SUM0 $2 \times \mathrm{O}_{3}\left[\mu 11^{-1} \mathrm{~h}\right]$ & 47.7 & 52.2 & 64.1 & 35.6 & 31.7 & 13.4 \\
\hline
\end{tabular}

to sun and shade leaves). Canopy air from all sampling positions was sucked through PVC tubes by means of membrane pumps, analyzed for $\mathrm{CO}_{2}$ concentration (infra-red gas analyzer (IRGA), Binos 4b.1, Rosemount AG, Hanau) and sampled once a day $(\sim 12: 00 \mathrm{LT})$ using a $100 \mathrm{ml}$ syringe. Gas samples were flushed through $12 \mathrm{ml}$ Exetainer vials and analyzed as detailed above.

During labeling, $\delta^{13} \mathrm{C}$ of canopy air was effectively decreased. Compared to the unlabeled beech control, mean reductions in sun and shade crowns under $1 \times \mathrm{O}_{3}$ were $8.1 \pm 0.2$ and $8.9 \pm 0.3 \%$, respectively, and under $2 \times \mathrm{O}_{3}$ $9.2 \pm 0.4$ and $8.4 \pm 0.5 \%$, respectively, (Table $2 b$ ). In spruce, mean reductions under $1 \times \mathrm{O}_{3}$ were $6.0 \pm 0.6 \%$ and $6.3 \pm 0.8 \%$, respectively, and under $2 \times \mathrm{O}_{3}, 7.5 \pm 0.9 \%$ and $6.5 \pm 0.7 \%$, respectively (Table $2 \mathrm{a}$ ). $\mathrm{CO}_{2}$ concentration in the canopy air of beech under both $\mathrm{O}_{3}$ regimes was increased by about $110 \mu 1^{-1}$ and in spruce by about $80 \mu 1^{-1}$ (Table $2 \mathrm{a})$. In both species, $\left[\mathrm{CO}_{2}\right]$ and $\delta^{13} \mathrm{C}$ of canopy air were each similar before and after labeling. Release of $\mathrm{CO}_{2}$ and thus label application in beech exceeded that of the spruce experiment. The increase in $\mathrm{CO}_{2}$ concentration of the canopy air did not affect the sap flow of labeled trees, suggesting unchanged stomatal conductance at the leaf level (Grams et al., 2011). Hence, the rate of $\mathrm{CO}_{2}$ uptake was assumed to rise to some extent, while the increase in leaf internal to external $\mathrm{CO}_{2}$ concentration was estimated to be small $(<0.02)$. Therefore, changes in photosynthetic discrimination against ${ }^{13} \mathrm{C}$ were calculated to stay below $0.4 \%$ (Grams et al., 2011).

\subsection{Assessment of stem and coarse $\operatorname{root} \mathrm{CO}_{2}$ efflux}

Stem and coarse root $\mathrm{CO}_{2}$ efflux $(E)$ of labeled and unlabeled control trees was assessed by means of a computercontrolled open gas exchange system (for details see Grams et al., 2011). Plexiglas chambers (Plexiglas ${ }^{\circledR}$, Röhm GmbH, Darmstadt, Germany) were attached at a lower and upper stem position and at one coarse root per tree (except for the unlabeled control spruce tree). Chambers were darkened with aluminized polyester foil to avoid refixation of efflux $\mathrm{CO}_{2}$ by corticular photosynthesis. For assessment of $\mathrm{CO}_{2}$ efflux, chambers were connected through PVC tubing to an IRGA (Binos 4b, Emerson Process Management, Weißling, Germany). Stem $\mathrm{CO}_{2}$ efflux was based on the volume ( $V$ in $\mathrm{m}^{3}$ ) of the stem sector behind the chamber (i.e. living tissue of bark and sapwood) and coarse root $\mathrm{CO}_{2}$ efflux on the totally enclosed coarse root volume, respectively (Desrochers et al., 2002; Saveyn et al., 2008).

\section{$2.6 \quad \delta^{13} \mathrm{C}$ of stem and coarse root $\mathrm{CO}_{2}$ efflux}

Data on $\delta^{13} \mathrm{C}$ of $\mathrm{CO}_{2}$ efflux $\left(\delta^{13} \mathrm{C}_{\mathrm{E}}\right)$ sampled from stems and coarse roots are shown as $24 \mathrm{~h}$-means $( \pm \mathrm{SE})$. Coarse root $\delta^{13} C_{\mathrm{E}}$ was assessed once per day (between 10:00 and 13:00 LT) by means of a closed respiration system (for details see Grams et al., 2011). A total of six $12 \mathrm{ml}$ Exetainer vials were subsequently flushed with chamber air of increasing $\mathrm{CO}_{2}$ concentration and $\delta^{13} \mathrm{C}_{\mathrm{E}}$ of coarse roots was calculated according to the "Keeling Plot approach" (Keeling, 1958, 1961). Air from stem respiration chambers was 


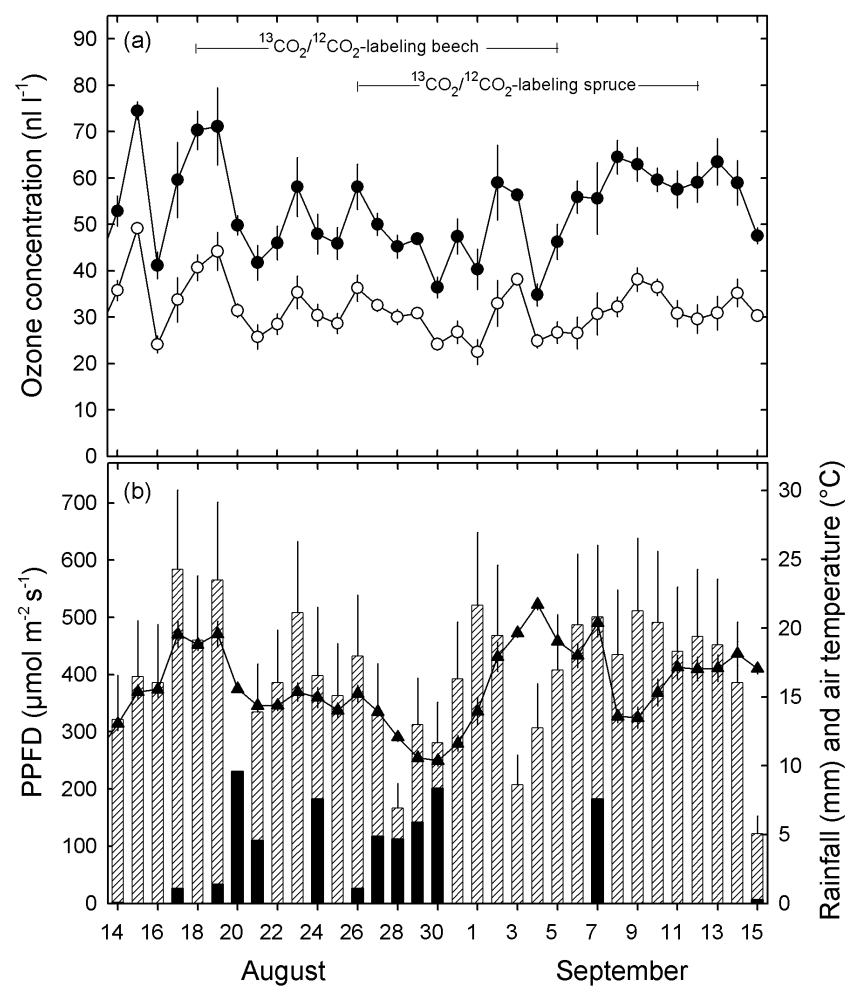

Fig. 1. Ozone concentrations and weather conditions during label exposure. (a) $1 \times$ (open circles) and $2 \times \mathrm{O}_{3}$ (closed circles). (b) Daily sums of photosynthetic photon flux density (PPFD) given as means of daylight hours \pm SE (hatched bars), daily means of air temperature ( \pm SE, triangles) and sums of rainfall (black bars).

automatically sampled in $12 \mathrm{ml}$ Exetainer vials, which were flushed with sample gas for six minutes each, at a flow rate of $0.151 \mathrm{~min}^{-1}$. A total of eight samples per day and chamber were assessed. Isotopic signature of $\mathrm{CO}_{2}$ efflux of the stem was calculated after Eq. (1) using a two end-member mixing model.

$\delta^{13} \mathrm{C}_{\mathrm{E}}=\frac{\left(\left[\mathrm{CO}_{2}\right]_{\text {sample }} \cdot \delta{ }^{13} \mathrm{C}_{\text {sample }}\right)-\left(\left[\mathrm{CO}_{2}\right]_{\text {reference }} \cdot \delta^{13} \mathrm{C}_{\text {reference }}\right)}{\left(\left[\mathrm{CO}_{2}\right]_{\text {sample }}\right)-\left(\left[\mathrm{CO}_{2}\right]_{\text {reference }}\right)}(\%)$

where, $\left[\mathrm{CO}_{2}\right]_{\text {sample }}=\mathrm{CO}_{2}$ concentration of sample gas from a stem respiration chamber $\left(\mu 1^{-1}\right), \quad\left[\mathrm{CO}_{2}\right]_{\text {reference }}=\mathrm{CO}_{2}$ concentration of reference gas from an empty chamber $\left(\mu 11^{-1}\right), \delta^{13} \mathrm{C}_{\text {sample }}=\delta^{13} \mathrm{C}$ of sample gas from a stem respiration chamber $(\% o)$ and $\delta^{13} \mathrm{C}_{\text {reference }}=\delta^{13} \mathrm{C}$ of reference gas from an empty chamber (\%o).

We considered that stem $\mathrm{CO}_{2}$ efflux may not only consist of local tissue-respired $\mathrm{CO}_{2}$, but may be biased by xylemtransported $\mathrm{CO}_{2}$ deriving from lower stem parts and/or root respiration (Teskey et al., 2008). However, the absent correlation between xylem sap flow and stem respiration rate or $\delta^{13} \mathrm{C}_{\mathrm{E}}$ (data not shown) suggests xylem-transported $\mathrm{CO}_{2}$ to only marginally interfere with sampled $\mathrm{CO}_{2}$ or to originate from similar respiratory processes as the locally respired $\mathrm{CO}_{2}$ behind the stem chamber.

\subsection{Fraction of labeled $\mathrm{C}$ in stem respiration}

The fraction of labeled carbon $\left(f_{\mathrm{E}, \text { new }}\right)$ in $\mathrm{CO}_{2}$ efflux $(E)$ was calculated following Lehmeier et al. (2008) and Gamnitzer et al. (2009):

$f_{\text {E,new }}=\left(\delta^{13} \mathrm{C}_{\text {sample }}-\delta^{13} \mathrm{C}_{\text {old }}\right) /\left(\delta^{13} \mathrm{C}_{\text {new }}-\delta^{13} \mathrm{C}_{\text {old }}\right)$

where, $\delta^{13} \mathrm{C}_{\text {old }}$ represents the $\delta^{13} \mathrm{C}$ of $E$ before labeling and $\delta^{13} \mathrm{C}_{\text {new }}$ the $\delta^{13} \mathrm{C}$ of $E$ of a tree grown (theoretically) continuously with labeled $\mathrm{CO}_{2}$. The labeling period of 18 to 19 days was too short to fully achieve new isotopic equilibrium in $E$ and therefore $\delta^{13} \mathrm{C}_{\text {new }}$ was derived from $\mathrm{C}$ isotope discrimination $\left(\Delta^{13} \mathrm{C}\right)$ before labeling, following Eqs. (3) and (4):

$\Delta^{13} \mathrm{C}=\left(\left[\delta^{13} \mathrm{C}_{\text {unlabeled air }}-\delta^{13} \mathrm{C}_{\text {old }}\right] /\left[1000+\delta^{13} \mathrm{C}_{\text {old }}\right]\right) \cdot 1000(\%$ o $)$

$\delta^{13} \mathrm{C}_{\text {new }}=\left(\left[\delta^{13} \mathrm{C}_{\text {labeled air }}-\Delta^{13} \mathrm{C}\right] /\left[1000+\Delta{ }^{13} \mathrm{C}\right]\right) \cdot 1000(\% o)$

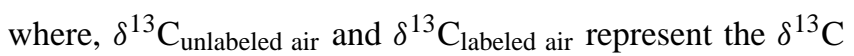
of canopy air before and during the labeling, respectively.

Day-to-day variation in $\delta^{13} \mathrm{C}_{\mathrm{E}}$ may occur from variations in label incorporation and in $\Delta^{13} \mathrm{C}$ depending on weather conditions (Pate and Arthur, 1998; Bowling et al., 2008). Thus, $\delta^{13} \mathrm{C}_{\mathrm{E}}$ of the labeled trees were corrected for the dayto-day variations in $\Delta^{13} \mathrm{C}$ (being rather small, i.e. $<0.5 \%$ ) of the unlabeled control trees, which showed rather stable $\delta^{13} \mathrm{C}_{\mathrm{E}}$ throughout the experiment, i.e. $22.4 \pm 0.1$ and $21.4 \pm 0.1 \%$ o for the upper and lower stem positions of beech, respectively, and $19.4 \pm 0.1 \%$ for the lower stem position of spruce.

\subsection{Assessment of $\delta^{13} \mathrm{C}$ of phloem sugars}

Phloem sap was sampled on day 0 and during the last labeling day from the lower stem position following the method of Gessler et al. (2004). Small pieces of bark with adherent phloem tissue $(\varnothing 5 \mathrm{~mm})$ were cored in the vicinity of the lower stem chamber and incubated $\left(5 \mathrm{~h}\right.$ at $\left.4{ }^{\circ} \mathrm{C}\right)$ in $15 \mathrm{mM}$ sodium polyphosphate buffer (Sigma-Aldrich, Munich, Germany). After centrifugation (12500 rpm, $5 \mathrm{~min}$ ), phloem sap was analyzed for water soluble sugars (sum of sucrose, fructose, glucose, raffinose and pinitol; i.e. $\mathrm{C}_{\mathrm{PS}}$ in $\mathrm{mg}$ ) by means of HPLC (CARBOsep CHO-820 calcium column, Transgenomic, 219 Glasgow, UK). Freeze-dried phloem sap was an-

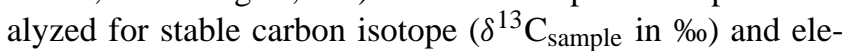
ment composition $\left(\mathrm{C}_{\text {sample }}\right.$ in $\mathrm{mg}$ ), and $\delta^{13} \mathrm{C}$ of phloem sugars $\left(\delta^{13} \mathrm{C}_{\mathrm{PS}}\right.$ in \%o) was calculated according to Eq. (5):

$\delta^{13} \mathrm{C}_{\mathrm{PS}}=\frac{\delta^{13} \mathrm{C}_{\text {sample }} \cdot \mathrm{C}_{\text {sample }}-\delta^{13} \mathrm{C}_{\mathrm{NPS}} \cdot \mathrm{C}_{\text {NPS }}}{\mathrm{C}_{\mathrm{PS}}}$

with $\delta^{13} \mathrm{C}_{\mathrm{NPS}}$ representing $\delta^{13} \mathrm{C}$ of non-sugar $\mathrm{C}$ (assuming $\delta^{13} \mathrm{C}_{\mathrm{NPS}}$ to correspond to $\delta^{13} \mathrm{C}_{\text {sample before labeling, }}$ cf. Grams et al., 2011) and $\mathrm{C}_{\mathrm{NPS}}$ (in $\mathrm{mg}$ ) denoting the nonsugar $\mathrm{C}$ content after labeling (calculated as difference between $\mathrm{C}_{\text {sample }}$ and $\mathrm{C}_{\mathrm{PS}}$ ) in the phloem sap. 
Table 2. (A) $\mathrm{CO}_{2}$ concentration $\left(\mu 11^{-1}\right)$ and (B) $\delta^{13} \mathrm{C}(\% \circ)$ in canopy air of labeled beech and spruce trees under $1 \times$ and $2 \times \mathrm{O}_{3}$ and one unlabeled control tree for each species. Data are presented for sun and shade crowns as means \pm SE before $(n=12 \mathrm{~h})$, during $(n=18$ to 19 days) and after $(n=12 \mathrm{~h})$ label exposure.

\begin{tabular}{|c|c|c|c|c|c|c|c|c|c|c|}
\hline & \multicolumn{2}{|c|}{ Unlabeled Control } & \multicolumn{4}{|c|}{ Labeled beech } & \multicolumn{4}{|c|}{ Labeled spruce } \\
\hline & \multirow[b]{2}{*}{ Sun } & \multirow[b]{2}{*}{ Shade } & \multicolumn{2}{|c|}{$1 \times \mathrm{O}_{3}$} & \multicolumn{2}{|c|}{$2 \times \mathrm{O}_{3}$} & \multicolumn{2}{|c|}{$1 \times \mathrm{O}_{3}$} & \multicolumn{2}{|c|}{$2 \times \mathrm{O}_{3}$} \\
\hline & & & Sun & Shade & Sun & Shade & Sun & Shade & Sun & Shade \\
\hline \multicolumn{11}{|c|}{$\mathrm{A}\left[\mathrm{CO}_{2}\right]\left(\mu \mathrm{l}^{-1}\right)$} \\
\hline Before & $384 \pm 2$ & $380 \pm 2$ & $383 \pm 3$ & $379 \pm 4$ & $384 \pm 8$ & $379 \pm 1$ & $382 \pm 6$ & $381 \pm 9$ & $382 \pm 21$ & $383 \pm 14$ \\
\hline During & $384 \pm 1$ & $385 \pm 1$ & $488 \pm 5$ & $505 \pm 9$ & $508 \pm 6$ & $498 \pm 7$ & $455 \pm 3$ & $460 \pm 5$ & $473 \pm 4$ & $465 \pm 8$ \\
\hline After & $385 \pm 7$ & $384 \pm 7$ & $380 \pm 2$ & $382 \pm 2$ & $380 \pm 5$ & $383 \pm 7$ & $383 \pm 8$ & $381 \pm 10$ & $381 \pm 7$ & $385 \pm 3$ \\
\hline \multicolumn{11}{|c|}{ B $\delta^{13} \mathrm{C}(\% \circ)$} \\
\hline Before & $-8.2 \pm 0.1$ & $-8.2 \pm 0.1$ & $-8.6 \pm 0.3$ & $-8.1 \pm 0.2$ & $-8.4 \pm 0.3$ & $-8.1 \pm 0.5$ & $-8.5 \pm 0.6$ & $-8.3 \pm 1.2$ & $-8.4 \pm 1.0$ & $-8.3 \pm 1.1$ \\
\hline During & $-8.6 \pm 0.1$ & $-8.6 \pm 0.1$ & $-16.7 \pm 0.3$ & $-17.5 \pm 0.5$ & $-17.8 \pm 0.4$ & $-17.0 \pm 0.4$ & $-14.6 \pm 0.2$ & $-14.9 \pm 0.3$ & $-16.0 \pm 0.3$ & $-15.1 \pm 0.5$ \\
\hline After & $-8.7 \pm 0.2$ & $-8.2 \pm 0.2$ & $-8.2 \pm 0.1$ & $-8.5 \pm 0.3$ & $-8.2 \pm 0.5$ & $-8.5 \pm 0.4$ & $-8.5 \pm 0.5$ & $-8.3 \pm 0.4$ & $-8.3 \pm 0.8$ & $-8.4 \pm 0.2$ \\
\hline
\end{tabular}

\subsection{Sampling of leaves and fine roots}

Leaves and fine roots were sampled before and during the last labeling day. Leaves were collected with different exposure to compass directions in sun and shade crowns. Recently grown fine roots $(\leq 2 \mathrm{~mm}$ diameter) of labeled and control trees were sampled from organic soil horizons $(<10 \mathrm{~cm}$ soil depth) and cleaned from soil with distilled water. Dried plant material $\left(72 \mathrm{~h}\right.$ at $\left.65^{\circ} \mathrm{C}\right)$ was fine-ground and weighed into tin capsules for $\delta^{13} \mathrm{C}$ analysis.

\subsection{Assessment of $\delta^{13} \mathrm{C}$ of soil respired $\mathrm{CO}_{2}$}

Soil gas samples were collected as detailed by Andersen et al. (2010). In brief, specific soil-gas sampling wells were placed belowground prior to tree labeling (distance from bole base of about 0.2 to $0.5 \mathrm{~m}$ ) at $8 \mathrm{~cm}$ and $15 \mathrm{~cm}$ depth. Teflon tubing was used to draw 5-8 $\mathrm{ml}$ of soil gas from each sampler using a gas-tight syringe. Each beech and spruce tree served as its own control by following the change in $\delta^{13} \mathrm{C}$ of soil-respired $\mathrm{CO}_{2}$ throughout 2.5 weeks of labeling. In the case of beech, a total of four soil-gas sampling wells were additionally installed at an unlabeled control plot. Gas samples were subsequently filled into $12 \mathrm{ml}$ Exetainer vials and analyzed for $\delta^{13} \mathrm{C}$. Calculation of $\delta^{13} \mathrm{C}$ of soil-respired $\mathrm{CO}_{2}$ follows Eq. (1), while $\mathrm{CO}_{2}$ of ambient air above the soil served as reference. Note that soil $\mathrm{CO}_{2}$ efflux was not adjusted by $-4.4 \%$ to account for the more rapid diffusion of ${ }^{12} \mathrm{C}$ compared to ${ }^{13} \mathrm{C}$ (Andersen et al., 2010). $\delta^{13} \mathrm{C}$ analysis of additional gas samples taken directly above the forest floor indicated that $\mathrm{CO}_{2}$ label was restricted to the crown and did not reach the forest soil (Grams et al., 2011).

\subsection{Statistical analyses}

Statistical analysis was performed using the SPSS 16.0 software package (SPSS Inc., Chicago, USA). Individual study trees were regarded as experimental units, and beech and spruce were analyzed separately. Data were statistically analyzed using General Linear Model (GLM) approach and ttests where appropriate. Statistical evaluation of the course in $\delta^{13} \mathrm{C}_{\mathrm{E}}$ of stems and coarse roots and the fraction of labeled $\mathrm{C}$ in stem $\mathrm{CO}_{2}$ efflux and coarse root $\mathrm{CO}_{2}$ efflux of labeled trees was performed using repeated measures analysis of variance. Differences at $p \leq 0.05$ were regarded as statistically significant, and at $p \leq 0.1$ as marginally, and denoted by * and $(*)$, respectively.

\section{Results}

\subsection{Stem and coarse root $\mathrm{CO}_{2}$ efflux}

In general, both species displayed up to 4 times higher (beech) and up to 2 times higher (spruce) $\mathrm{CO}_{2}$ efflux rates at the upper compared to the lower stem position (Table 3), whereas rates of coarse roots were 10 to 60 times higher than in stems. In beech, $2 \times \mathrm{O}_{3}$ significantly diminished the $\mathrm{CO}_{2}$ efflux rate of the upper stem (by ca. $-60 \%$ ), but caused a pronounced, but only marginally significant $(p=0.065)$, increase in coarse roots (by ca. $+65 \%$ ). In spruce, $\mathrm{CO}_{2}$ efflux rate of the upper stem position was significantly increased under $2 \times \mathrm{O}_{3}$ (by ca. $90 \%$ ), whereas this effect was much smaller (ca. $20 \%$ ) and statistically not significant at the lower stem position. However, long-term exposure to $2 \times \mathrm{O}_{3}$ reduced the $\mathrm{CO}_{2}$ efflux rate of spruce coarse roots by ca. $25 \%$ (not statistically significant, $p=0.157$ ).

\section{2 $\delta^{13} \mathrm{C}$ in stem and coarse $\operatorname{root} \mathrm{CO}_{2}$ efflux}

Before labeling, daily means $( \pm \mathrm{SE})$ of $\delta^{13} \mathrm{C}_{\mathrm{E}}$ in beech trees were $-28.2 \pm 0.1$ and $-27.9 \pm 0.4 \%$ at the upper and lower stem position under $1 \times \mathrm{O}_{3}$, respectively (Fig. 2). Exposure to $2 \times \mathrm{O}_{3}$ slightly increased values by about $0.4 \%$ (not 
Table 3. Stem and coarse root $\mathrm{CO}_{2}$ efflux $\left(\mu \mathrm{mol} \mathrm{m} \mathrm{m}^{-3} \mathrm{~s}^{-1}\right)$ of beech and spruce during the 2.5 weeks of labeling. Data are shown as means $\pm \mathrm{SE}$ ( $n=3$ trees). Within one species, lowercase letters denote significant differences among upper and lower stems $\left({ }^{\mathrm{a}}, \mathrm{b}\right)$ and lower stems and coarse roots $\left({ }^{\mathrm{c}}, \mathrm{d}\right)$, respectively $(p \leq 0.05)$. Asterisks denote significant differences between $\mathrm{O}_{3}$ regimes $(p \leq 0.05)$. Statistical evaluation was performed using the t-test for paired comparisons.

\begin{tabular}{cccccc}
\hline & \multicolumn{2}{c}{ Beech } & & \multicolumn{2}{c}{ Spruce } \\
\cline { 2 - 3 } \cline { 5 - 6 } & $1 \times \mathrm{O}_{3}$ & $2 \times \mathrm{O}_{3}$ & & $1 \times \mathrm{O}_{3}$ & $2 \times \mathrm{O}_{3}$ \\
\hline Upper Stem & $14.1 \pm 2.7^{\mathrm{a}}$ & $5.5 \pm 1.1^{\mathrm{a} *}$ & & $12.8 \pm 0.6^{\mathrm{a}}$ & $24.6 \pm 1.6^{\mathrm{a} *}$ \\
Lower Stem & $3.8 \pm 1.8^{\mathrm{b}, \mathrm{c}}$ & $4.9 \pm 1.9^{\mathrm{a}, \mathrm{c}}$ & & $11.9 \pm 0.9^{\mathrm{a}, \mathrm{c}}$ & $14.7 \pm 4.0^{\mathrm{b}, \mathrm{c}}$ \\
Coarse root & $166.3 \pm 62.0^{\mathrm{d}}$ & $272.2 \pm 71.2^{\mathrm{d}}$ & & $554.6 \pm 94.1^{\mathrm{d}}$ & $412.0 \pm 108.3^{\mathrm{d}}$ \\
\hline
\end{tabular}

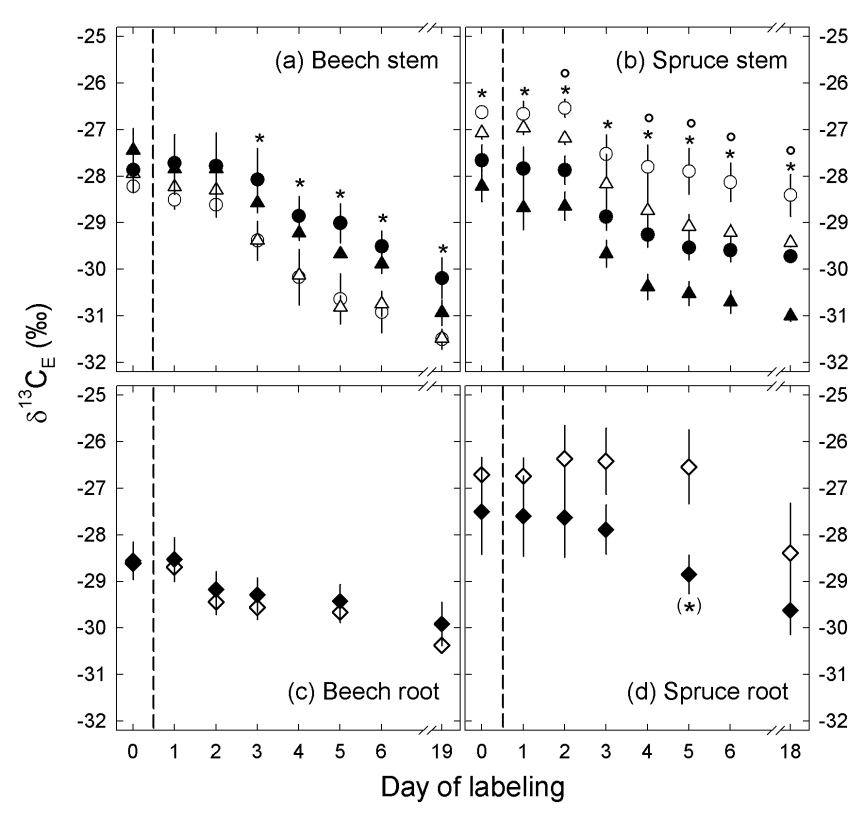

Fig. 2. Course in $\delta^{13} \mathrm{C}_{\mathrm{E}}$ of stems (triangles: upper stem, circles: lower stem) and coarse roots (diamonds) of labeled beech (a, c) and spruce (b, d) under $1 \times$ (white) and $2 \times \mathrm{O}_{3}$ (black) (daily means $\pm \mathrm{SE}, n=3$ trees) during labeling. Consideration was given to the initial difference in $\delta^{13} \mathrm{C}_{\mathrm{E}}$ by using data of day 0 as covariate. Dashed line indicates the initiation of the label application. Significant differences between $\mathrm{O}_{3}$ regimes and stem positions at $p \leq 0.05$ are indicated by $*$ and ${ }^{\circ}$, respectively. Marginal significance at $p \leq 0.10$ is denoted by $(*)$. Statistical evaluation was performed using repeated measures analysis of variance.

statistically significant). In spruce, $\delta^{13} \mathrm{C}_{\mathrm{E}}$ of the upper and lower stems were $-27.1 \pm 0.1$ and $-26.6 \pm 0.1 \%$, respectively. Here $2 \times \mathrm{O}_{3}$ significantly reduced values by about $1.1 \%$. In both species, $\delta^{13} \mathrm{C}_{\mathrm{E}}$ of coarse roots were similar to the values of the lower stems and responses to $2 \times \mathrm{O}_{3}$ were consistent with stems.

While unlabeled control trees displayed minor day-today variations in $\delta^{13} \mathrm{C}_{\mathrm{E}}$ of the various organs during labeling $(\mathrm{SD}<0.3 \%$ ), labeled trees displayed decreasing val- ues upon label application (Fig. 2). In beech, $\delta^{13} \mathrm{C}_{\mathrm{E}}$ of the stems decreased from day 2 onwards under both $\mathrm{O}_{3}$ regimes (Fig. 2a), with a significantly more pronounced decline under $1 \times \mathrm{O}_{3}$. Likewise, coarse root $\delta^{13} \mathrm{C}_{\mathrm{E}}$ decreased from day 2 onwards (Fig. 2c), although this effect was less prominent than in stems. Similar to beech, $\delta^{13} \mathrm{C}_{\mathrm{E}}$ of stems in spruce decreased from day 3 onwards under both $\mathrm{O}_{3}$ regimes (Fig. 2b). Contrasting with beech, the decline was significantly stronger under $2 \times \mathrm{O}_{3}$ and more pronounced in the upper compared to the lower stem position $(p<0.05$, except for day 3). In coarse roots, the decline in $\delta^{13} \mathrm{C}_{\mathrm{E}}$ was somewhat delayed, in particular under $1 \times \mathrm{O}_{3}$ and somewhat stronger under $2 \times \mathrm{O}_{3}(p=0.085$ at day 5 , Fig. $2 \mathrm{~d})$.

\subsection{Fraction of labeled $\mathrm{C}$ in stem and coarse root $\mathrm{CO}_{2}$ efflux}

In beech, the fraction of labeled carbon $\left(f_{\mathrm{E}, \text { new }}\right)$ in stem $\mathrm{CO}_{2}$ efflux started to increase during labeling day 2 and was significantly lower in $2 \times \mathrm{O}_{3}$ compared to $1 \times \mathrm{O}_{3}$ from day 3 onwards (Fig. 3a). At the end of the labeling period (day $19), f_{\mathrm{E}, \text { new }}$ had approached maximum levels of $0.40 \pm 0.01$ under $1 \times \mathrm{O}_{3}$, whereas under $2 \times \mathrm{O}_{3}$ only $0.33 \pm 0.06$ and $0.26 \pm 0.06$ at the upper and lower stem position, respectively, were reached. Lowest $f_{\mathrm{E}, \text { new }}$ was observed for coarse roots (maximum of 0.2 ), being significantly reduced under $2 \times \mathrm{O}_{3}$ from day 5 onwards (Fig. $3 \mathrm{c}$ ). In spruce, $f_{\mathrm{E} \text {, new }}$ of stem $\mathrm{CO}_{2}$ efflux started to increase on labeling day 2 , reaching maximum levels of $0.37 \pm 0.03$ (upper stem) and $0.25 \pm 0.05$ (lower stem) under $1 \times \mathrm{O}_{3}$, and $0.39 \pm 0.06$ and $0.30 \pm 0.02$, respectively, under $2 \times \mathrm{O}_{3}$ at the end of the labeling period (day 18, Fig. $3 \mathrm{~b}$ ). Increase of $f_{\mathrm{E}, \text { new }}$ in spruce coarse roots started somewhat delayed (day 3 ) but reached levels similar to those of the lower stem position (Fig. 3d). Contrasting with beech, $2 \times \mathrm{O}_{3}$ did not result in a consistently reduced $f_{\mathrm{E} \text {,new }}$ in stems and coarse roots. 


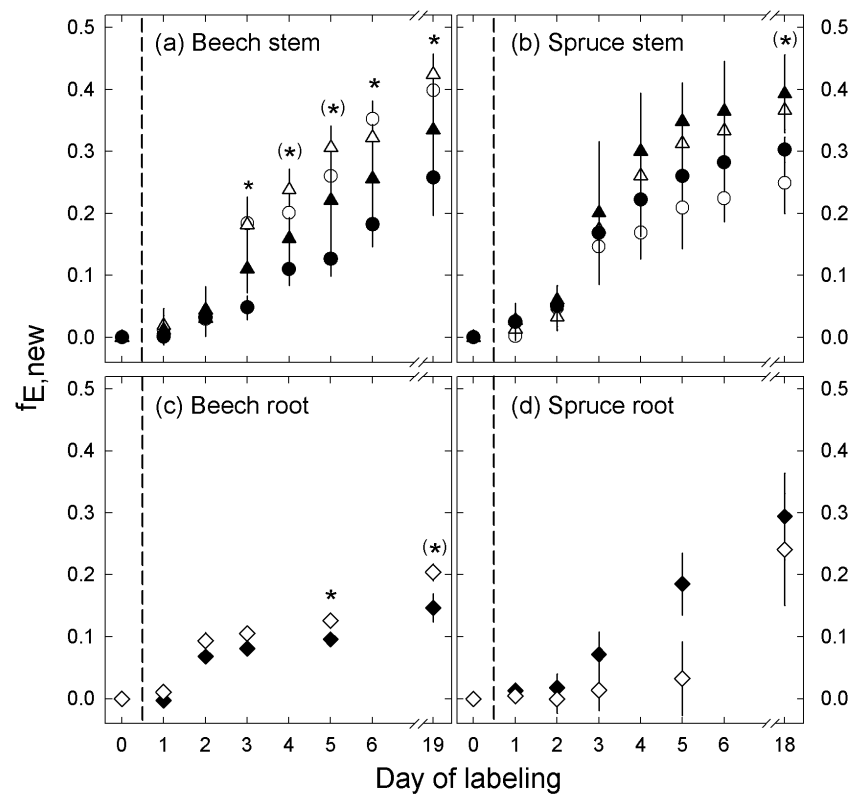

Fig. 3. Fraction of labeled $\mathrm{C}$ in stem $\mathrm{CO}_{2}$ efflux (triangles: upper stem, circles: lower stem) and coarse root $\mathrm{CO}_{2}$ efflux (diamonds) of labeled beech (a, c) and spruce $(\mathbf{b}, \mathbf{d})$ under $1 \times$ (white) and $2 \times \mathrm{O}_{3}$ (black) (daily means $\pm \mathrm{SE}, n=3$ trees). Dashed line indicates the initiation of the label application. Significant difference between $\mathrm{O}_{3}$ regimes at $p \leq 0.05$ is denoted by $*$. Marginal significance at $p \leq 0.10$ is denoted by $(*)$. Statistical evaluation was performed using repeated measures analysis of variance.

\section{$3.4 \quad \delta^{13} \mathrm{C}$ in leaves, phloem sugars, fine roots and soil respired $\mathrm{CO}_{2}$ before labeling}

Before labeling, no apparent differences in $\delta^{13} \mathrm{C}$ caused by the long-term $2 \times \mathrm{O}_{3}$ exposure were found in the foliage, phloem sap of the stem, fine roots and soil respired $\mathrm{CO}_{2}$ in either species (Table 4). In general, $\delta^{13} \mathrm{C}$ in the sun leaves was significantly increased by ca. $3 \%$ (beech) and $2 \%$ (spruce) compared with shade leaves each. The $\delta^{13} \mathrm{C}$ of soil-respired $\mathrm{CO}_{2}$ underneath beech of about $-24 \%$ was not affected by the $\mathrm{O}_{3}$ treatment. In comparison with beech, all samples from spruce were enriched in ${ }^{13} \mathrm{C}$ by 1 to $2 \%$ o $(p \leq 0.05)$. In spruce, $\delta^{13} \mathrm{C}$ of soil respired $\mathrm{CO}_{2}$ was reduced by about $1.2 \%$ under $2 \times \mathrm{O}_{3}$ and increased by about $1.0 \%$ at a soil depth of $15 \mathrm{~cm}$ compared to $8 \mathrm{~cm}$.

\subsection{Shift in $\delta^{13} \mathrm{C}$ of $\mathrm{CO}_{2}$ efflux and organic material by the end of labeling}

During the 2.5 week labeling period, the $\delta^{13} \mathrm{C}$ of stem and root $\mathrm{CO}_{2}$ efflux, soil-respired $\mathrm{CO}_{2}$ and organic samples (phloem sugars, leaves and fine roots) in the unlabeled control trees of both species was only marginally affected $\left(<0.5 \%\right.$ o, Fig. 4). In labeled beech, the drop in $\delta^{13} \mathrm{C}_{\mathrm{E}}$ at the end of label application in the upper stem position was unaffected by $\mathrm{O}_{3}\left(3.5 \pm 0.2 \%\right.$ in both $\mathrm{O}_{3}$ treatments), but less pronounced at the lower stem position under $2 \times \mathrm{O}_{3}$ $\left(3.3 \pm 0.1 \%\right.$ and $2.3 \pm 0.5 \%$ under $1 \times$ and $2 \times \mathrm{O}_{3}$, respectively) (Fig. 4b, c). Phloem sugars sampled from the lower stem position displayed similar shifts in $\delta^{13} \mathrm{C}$ of $4.0 \pm 1.4 \%$ o and $3.5 \pm 0.6 \%$ under $1 \times$ and $2 \times \mathrm{O}_{3}$, respectively. In consistency with the reduced label strength in spruce canopy air (about $6.0 \%$ compared to $8.2 \%$ in beech), the drop in stem $\delta^{13} \mathrm{C}_{\mathrm{E}}$ of spruce was lower than in beech (Fig. 4e, f). Conversely to beech, the drop was somewhat increased by $2 \times \mathrm{O}_{3}$ : upper and lower stem position of $2.4 \pm 0.2 \%$ and $1.8 \pm 0.3 \%$ o under $1 \times \mathrm{O}_{3}$, respectively, and $2.8 \pm 0.2 \% 0$ and $2.1 \pm 0.2 \%$ ouder $2 \times \mathrm{O}_{3}$, respectively. Again, a similar shift was observed in phloem sugars $(3.2 \pm 0.3 \%$ and $2.5 \pm 0.2 \%$ under $1 \times$ and $2 \times \mathrm{O}_{3}$, respectively). Corresponding changes of $\delta^{13} \mathrm{C}$ in leaf bulk material were much smaller (about $1.5 \%$ ).

Upon labeling, belowground allocation of recent photosynthates was not affected by the $\mathrm{O}_{3}$ treatment and, in general, was reduced compared to stem $\mathrm{CO}_{2}$ efflux and phloem sugars. The decline upon labeling in $\delta^{13} \mathrm{C}_{\mathrm{E}}$ of coarse roots was $1.8 \pm 0.1 \%$ and $1.4 \pm 0.1 \%$ in beech and $1.7 \pm 0.9 \%$ o and $2.1 \pm 0.8 \%$ in spruce under $1 \times$ and $2 \times \mathrm{O}_{3}$, respectively. Under beech, changes in $\delta^{13} \mathrm{C}$ of soil-respired $\mathrm{CO}_{2}$ were similar to coarse roots $\delta^{13} \mathrm{C}_{\mathrm{E}}$ (about 1.5 to $2.5 \%$ ), whereas soil $\mathrm{CO}_{2}$ under spruce remained unchanged (Fig. 4e, f). Similar to leaf bulk material, $\delta^{13} \mathrm{C}$ of fine roots displayed smaller changes than sampled $\mathrm{CO}_{2}$ efflux and was in the range of $0.5 \%$, irrespective of the $\mathrm{O}_{3}$ treatment.

\section{Discussion}

Our study compares the flux of recent photosynthates to the $\mathrm{CO}_{2}$ efflux of stems and coarse roots in adult deciduous beech and evergreen spruce during summer and in response to seven-year long $2 \times \mathrm{O}_{3}$ treatment. The hypothesis I that long-term exposure to elevated $\mathrm{O}_{3}$ reduces the flux of recently fixed $\mathrm{C}$ to $\mathrm{CO}_{2}$ efflux of stems and coarse roots was accepted for beech but rejected in the case of spruce, which is in accordance with their contrasting $\mathrm{O}_{3}$ sensitivities (support for hypothesis II).

Long-term exposure to $2 \times \mathrm{O}_{3}$ for seven years did not significantly affect the $\delta^{13} \mathrm{C}$ of beech and spruce leaves or sugars transported in the phloem sap during late summer (Table 4, cf. Grams et al., 2007; Gessler et al., 2009). Nevertheless, $\delta^{13} \mathrm{C}$ of beech sun leaves displayed a tendency similar to that reported by Kitao et al. (2009) in that $2 \times \mathrm{O}_{3}$ increased $\delta^{13} \mathrm{C}$ of leaf dry matter caused by $\mathrm{O}_{3}$-induced stomatal closure. Likewise, spruce displayed some photosynthetic and stomatal limitation under $2 \times \mathrm{O}_{3}$ although varying from year to year (Nunn et al., 2005b, 2006). In general, $\delta^{13} \mathrm{C}$ of leaf and fine root biomass was about $2 \%$ o higher in spruce compared to beech, likely resulting from higher leaf-level water-use efficiency in the evergreen conifer compared to deciduous trees 
Table 4. $\delta^{13} \mathrm{C}(\% \circ)$ of sun and shade leaves, phloem sugars, fine roots and soil respired $\mathrm{CO}_{2}$ of beech and spruce before labeling. Data are shown as means $\pm \mathrm{SE}$ ( $n=3$ trees). Lowercase letters denote significant differences between crown levels and soil depths $(p \leq 0.05)$. Statistical evaluation was performed using the t-test for paired comparisons.

\begin{tabular}{|c|c|c|c|c|}
\hline & \multicolumn{2}{|c|}{ Beech } & \multicolumn{2}{|c|}{ Spruce } \\
\hline & $1 \times \mathrm{O}_{3}$ & $2 \times \mathrm{O}_{3}$ & $1 \times \mathrm{O}_{3}$ & $2 \times \mathrm{O}_{3}$ \\
\hline Phloem sugars & $-29.1 \pm 0.3$ & $-29.5 \pm 0.3$ & $-27.0 \pm 0.4$ & $-27.5 \pm 0.5$ \\
\hline \multicolumn{5}{|l|}{ Leaves } \\
\hline Sun & $-28.3 \pm 0.1^{\mathrm{a}}$ & $-28.0 \pm 0.3^{\mathrm{a}}$ & $-26.4 \pm 0.5^{\mathrm{a}}$ & $-27.3 \pm 0.2^{\mathrm{a}}$ \\
\hline Shade & $-31.3 \pm 0.3^{\mathrm{b}}$ & $-31.6 \pm 0.3^{b}$ & $-28.6 \pm 0.4^{b}$ & $-29.6 \pm 0.6^{b}$ \\
\hline Fine roots* & $-28.6 \pm 0.2$ & $-28.4 \pm 0.2$ & $-26.4 \pm 0.3$ & $-26.5 \pm 0.2$ \\
\hline \multicolumn{5}{|l|}{ Soil-respired $\mathrm{CO}_{2}^{*}$} \\
\hline at $8 \mathrm{~cm}$ depth & $-24.4 \pm 0.2$ & $-24.0 \pm 0.6$ & $-23.1 \pm 0.3^{\mathrm{a}}$ & $-24.2 \pm 0.5$ \\
\hline at $15 \mathrm{~cm}$ depth & $-24.5 \pm 0.2$ & $-23.8 \pm 0.2$ & $-22.0 \pm 0.4^{b}$ & $-23.3 \pm 0.4$ \\
\hline
\end{tabular}

* Data taken from Andersen et al. (2010).

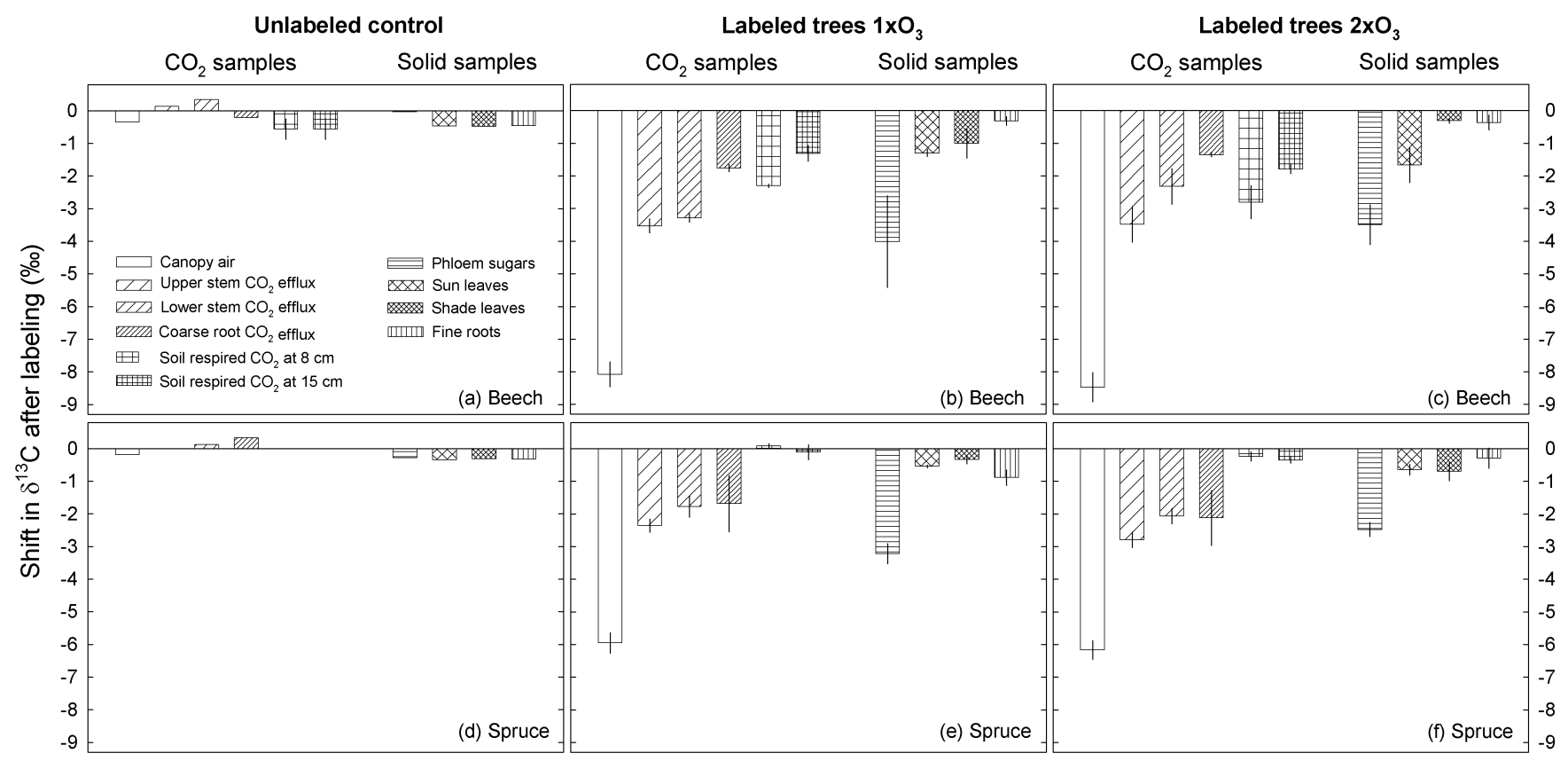

Fig. 4. Shift in $\delta^{13} \mathrm{C}$ of canopy air, upper and lower stem $\mathrm{CO}_{2}$ efflux, soil respired $\mathrm{CO}_{2}$ at 8 and $15 \mathrm{~cm}$ soil depth, phloem sugars, sun and shade leaves as well as fine roots of beech (a-c) and spruce (d-f) after 2.5 weeks of labeling. Data are shown as means $( \pm$ SE) for three labeled trees under $1 \times$ and $2 \times \mathrm{O}_{3}$, respectively. In addition, data from one unlabeled control beech and spruce tree are included to confirm no effect of weather conditions on $\delta^{13} \mathrm{C}$ during experimentation. Overall, the t-test for paired comparisons indicated no significant differences in $\delta^{13} \mathrm{C}$ shift between $\mathrm{O}_{3}$ regimes within $\mathrm{CO}_{2}$ and solid samples of labeled beech and spruce.

(Matyssek, 1986; Garten and Taylor, 1992; Diefendorf et al., 2010).

In both beech and spruce, labeled photosynthates were detected in the upper and lower stem $\mathrm{CO}_{2}$ efflux from day 3 onwards (Figs. 2 and 3). Thus, slower $\mathrm{C}$ transfer in the phloem of gymnosperms compared to angiosperms could not be confirmed (Kuptz et al., 2011a; Dannoura et al., 2011). The fraction of labeled $\mathrm{C}\left(f_{\mathrm{E} \text {,new }}\right)$ in the $\mathrm{CO}_{2}$ efflux of beech stems was significantly reduced under $2 \times \mathrm{O}_{3}$ (support of hy- pothesis I), indicating a higher dependency on $\mathrm{C}$ stores of the respiratory supply under $2 \times \mathrm{O}_{3}$ (cf. Ritter et al., 2011). Such a response may be caused by (1) a direct adverse effect of $\mathrm{O}_{3}$ on beech photosynthesis and thus reduced label uptake, although reductions were typically small (Nunn et al., 2005b; 2006), or (2) a changed $\mathrm{C}$ allocation pattern by e.g. an $\mathrm{O}_{3}$-inhibited assimilate transport from the leaves. As a consequence the respiratory activity of stem tissues may be restricted (Matyssek et al., 2002) and C stores in stems 
and roots may decrease towards the end of the growing season (McLaughlin et al., 1982). Consequently, re-growth and bud development in spring may become limited (Matyssek and Sandermann, 2003). The significantly decreased flux of recent photosynthates to beech stems represents the mechanistic basis for the observed loss in stem productivity of $40 \%$ under long-term exposure of $2 \times \mathrm{O}_{3}$ (Pretzsch et al., 2010). In consistency with model predictions (Sitch et al., 2007), this indicates the potential of chronic $\mathrm{O}_{3}$ stress to substantially mitigate the $\mathrm{C}$ sink strength of trees (Matyssek et al., 2010b). Contrasting with beech, exposure to $2 \times \mathrm{O}_{3}$ in tendency increased the fraction of labeled $\mathrm{C}\left(f_{\mathrm{E}, \text { new }}\right)$ in stem $\mathrm{CO}_{2}$ efflux of spruce, rejecting hypothesis I for spruce. At the same time, the rate of stem $\mathrm{CO}_{2}$ efflux was significantly increased under $2 \times \mathrm{O}_{3}$. Such a stimulation following $\mathrm{O}_{3}$ exposure has been reported in several studies on herbaceous plants (Grantz and Shrestha, 2006; Reiling and Davison, 1992) and is known to sustain repair- and detoxification processes (Matyssek et al., 1995; Rennenberg et al., 1996). The slightly increased $\mathrm{C}$ allocation to such processes in spruce may relate to its overall lower $\mathrm{O}_{3}$ sensitivity compared to beech (Kozovits et al., 2005a, b; Matyssek et al., 2010b; Pretzsch et al., 2010). Whereas under $2 \times \mathrm{O}_{3}$ allocation of $\mathrm{C}$ to reserves in beech stems may be restricted (Ritter et al., 2011) putatively reducing $C$ supply for stem growth in the following year.

We do not expect the observed $\mathrm{O}_{3}$ effects to be counteracted by the short-term increase in $\mathrm{CO}_{2}$ concentration during labeling as $\mathrm{CO}_{2} \times \mathrm{O}_{3}$ interactions in beech are typically related to reductions in stomatal aperture (Grams et al., 1999; Grams and Matyssek, 1999) that were absent during labelling (Grams et al., 2011). Moreover, adjustments of beech in response to the long-term exposure (i.e. $7 \mathrm{yr}$ ) to the $2 \times \mathrm{O}_{3}$ regime are unlikely to be ameliorated by short-term (i.e. 2.5 weeks) increases in $\mathrm{CO}_{2}$ concentration by about $100 \mu \mathrm{l}^{-1}$.

Reduction of $\delta^{13} \mathrm{C}$ in canopy air for 2.5 weeks by about 8 and $6 \%$ resulted in a drop of stem $\delta^{13} \mathrm{C}_{\mathrm{E}}$ in beech of 3$4 \%$ and in spruce by $2-3 \%$, respectively (Fig. $4 \mathrm{~b}-\mathrm{f}$ ). Correspondingly, $f_{\mathrm{E} \text {,new }}$ of stem $\mathrm{CO}_{2}$ efflux amounted to about 0.3 to 0.4 in both species. In parallel, $\delta^{13} \mathrm{C}$ of labeled phloem sugars was reduced to a similar extent by about 4 and $3 \%$ o in beech and spruce, respectively, suggesting respiration of phloem sugars to be the main $\mathrm{C}$ source for stem $\mathrm{CO}_{2}$ efflux (Kuptz et al., 2011a). Unlabeled $C$ in phloem sugars after 2.5 weeks of continuous labeling may derive from "old C" atoms in C skeletons of currently synthesized sucrose as a consequence of slow turnover of precursor molecules or from remobilized C stores (Gessler et al., 2008; Tcherkez et al., 2003). We note that $\mathrm{CO}_{2}$ efflux sampled from stems (and roots) may be affected by xylem-transported $\mathrm{CO}_{2}$ deriving from lower stem region and/or root respiration (Teskey et al., 2008). We did not find a correlation between sap flow and both rates of stem $\mathrm{CO}_{2}$ efflux and stem $\delta^{13} \mathrm{C}_{\mathrm{E}}$ in our study (cf. Grams et al., 2011; Kuptz et al., 2011a, b). Hence, contribution of xylem transported $\mathrm{CO}_{2}$ to sampled $\mathrm{CO}_{2}$ efflux may be small or originate from similar respiratory processes as at the sampled stem position. In fact, the contribution from soil $\mathrm{CO}_{2}$ to stem $\mathrm{CO}_{2}$ efflux was recently concluded to be rather small (Gebhardt, 2008; Aubrey and Teskey, 2009; Ubierna et al., 2009). However, contribution of respiratory $\mathrm{CO}_{2}$ from lower parts of the stem or roots to sampled $\mathrm{CO}_{2}$ efflux can not be ruled out completely and the extent of this putative influence remains obscure.

In consistency with the findings on $\delta^{13} \mathrm{C}_{\mathrm{E}}$ in stems, $2 \times \mathrm{O}_{3}$ distinctly reduced $f_{\mathrm{E} \text {,new }}$ of coarse root efflux of beech, supporting hypothesis I. The decrease in coarse root $\delta^{13} \mathrm{C}_{\mathrm{E}}$ during the labeling in summer was about $1-2 \%$ o smaller than in stems, indicating a lower dependence of root $\mathrm{CO}_{2}$ efflux on recent photosynthates (Wingate et al., 2008; Bathellier et al., 2009; Kuptz et al., 2011a). However, soil-respired $\mathrm{CO}_{2}$, which includes large contributions by root-respired $\mathrm{CO}_{2}$ of unlabeled neighboring trees and heterotrophic soil respiration (Högberg et al., 2001; Andersen et al., 2005, 2010), was reduced in $\delta^{13} \mathrm{C}$ by 1.5 to $3 \%$. Hence, beech fine roots and associated micro organisms appear to be a relatively strong sink for recently fixed $\mathrm{C}$ during summer (Högberg et al., 2001; Plain et al., 2009; Epron et al., 2011). Slightly pronounced shifts in soil-respired $\mathrm{CO}_{2}$ under $2 \times \mathrm{O}_{3}$ fit well with previously reported increases in fine-root turn-over of beech under long-term $\mathrm{O}_{3}$ exposure (Nikolova et al., 2010). Similar to $\mathrm{C}$ flux in spruce stems, elevated $\mathrm{O}_{3}$ did not reduce the allocation of recent photosynthates to coarse root $\mathrm{CO}_{2}$ efflux during summer (cf. Andersen et al., 2010). However, the $\mathrm{C}$ label was hardly detectable in the soil-respired $\mathrm{CO}_{2}$ around the trees (Andersen et al., 2010), which may indicate favored allocation of labeled $\mathrm{C}$ to storage and/or structural pools in the fine roots during summer (cf. Kuptz et al., 2011a), resulting in the observed drop of $\delta^{13} \mathrm{C}$ in the fine root tissue during labeling (Fig. 4e, f).

In conclusion, the transfer of recently fixed $\mathrm{C}$ from beech and spruce crowns to stem and coarse root $\mathrm{CO}_{2}$ efflux within 2 to 3 days displays tight coupling with canopy photosynthesis during summer. Our labeling approach for tracking of individual, isotopically labeled sugar molecules through tall beech and spruce trees should not be confused with the faster propagation of phloem pressure-concentration waves (Kuzyakov and Garvrichkova, 2010; Mencuccini and Hölttä, 2010). Chronic exposure to $2 \times \mathrm{O}_{3}$ reduced allocation of photosynthates to the stem and coarse roots of beech and spruce in contrasting ways. The conifer spruce increased the flux of photosynthates to stems (rejection of hypothesis I for spruce), whereas this flux was restricted in stems and coarse roots of deciduous beech (acceptance of hypotheses I and II). The observed patterns in translocation of recent photosynthates are interpreted as a mechanistic basis for observed reductions in beech stem growth, highlighting the potential of chronic $\mathrm{O}_{3}$ stress to substantially mitigate the $\mathrm{C}$ sink strength of trees. 
Acknowledgements. We gratefully acknowledge the skillful assistance of T. Feuerbach, H. Lohner, P. Kuba, and J. Heckmair. The study was funded through SFB 607 "Growth and Parasite Defense-Competition for Resources in Economic Plants from Agronomy and Forestry, Projects B5" by the "Deutsche Forschungsgemeinschaft" (DFG). The authors also wish to thank B. Ozretich and A. Bytnerowicz for helpful comments on an earlier version of the manuscript. The information in this paper has been subjected to EPA peer and administrative review, and it has been approved for publication as an EPA document. Mention of trade names or commercial products does not constitute endorsement or recommendation for use.

Edited by: M. Bahn

\section{References}

Andersen, C. P.: Source-sink balance and carbon allocation below ground in plants exposed to ozone, New Phytol., 157, 213-228, 2003.

Andersen, C. P., Nikolov, I., Nikolova, P., Matyssek, R., and Häberle, K. H.: Estimating "autotrophic" belowground respiration in spruce and beech forests: decreases following girdling, Eur. J. Forest Res., 124, 155-163, 2005.

Andersen, C. P., Ritter, W., Gregg, J., Matyssek, R., and Grams, T. E. E.: Below-ground carbon allocation in mature beech and spruce trees following long-term, experimentally enhanced $\mathrm{O}_{3}$ exposure in Southern Germany, Environ. Pollut., 158, 26042609, 2010.

Aubrey, D. P. and Teskey, R. O.: Root-derived $\mathrm{CO}_{2}$ efflux via xylem stream rivals soil $\mathrm{CO}_{2}$ efflux, New Phytol., 184, 35-40, 2009.

Bathellier, C., Tcherkez, G., Bligny, R., Gout, E., Cornic, G., and Ghashghaie J.: Metabolic origin of the $\delta^{13} \mathrm{C}$ of respired $\mathrm{CO}_{2}$ in roots of Phaseolus vulgaris, New Phytol., 181, 387-399, 2009.

Bowling, D. R., Pataki, D. E., and Randerson, J. T.: Carbon isotopes in terrestrial ecosystem pools and $\mathrm{CO}_{2}$ fluxes, New Phytol., 178, 24-40, 2008.

Coleman, M. D., Dickson, R. E., Isebrands, J. G., and Karnosky, D. F.: Root growth and physiology of potted and field-grown trembling aspen exposed to ozone, Tree Physiol., 16, 145-152, 1996.

Dannoura, M., Maillard, P., Fresneau, C., Plain, C., Berveiller, D., Gerant, D., Chipeaux, C., Bosc, A., Ngao, J., Damesin, C., Loustau, D., and Epron, D.: In situ assessment of the velocity of carbon transfer by tracing ${ }^{13} \mathrm{C}$ in trunk $\mathrm{CO}_{2}$ efflux after pulse labelling: variations among tree species and seasons, New Phytol., 190, 181-192, 2011.

Desrochers, A., Landhausser, S. M., and Lieffers, V. J.: Coarse and fine root respiration in aspen (Populus tremuloides), Tree Physiol., 22, 725-732, 2002.

Diefendorf, A. F., Mueller, K. E., Wing, S. L., Koch, P. L., and Freeman, K. H.: Global patterns in leaf ${ }^{13} \mathrm{C}$ discrimination and implications for studies of past and future climate, P. Natl. Acad. Sci. USA, 107, 5738-5743, 2010.

Epron, D., Ngao, J., Dannoura, M., Bakker, M. R., Zeller, B., Bazot, S., Bosc, A., Plain, C., Lata, J. C., Priault, P., Barthes, L., and Loustau, D.: Seasonal variations of belowground carbon transfer assessed by in situ ${ }^{13} \mathrm{CO}_{2}$ pulse labelling of trees, Biogeosciences, 8, 1153-1168, doi:10.5194/bg-8-1153-2011, 2011.
Fowler, D., Cape, J. N., Coyle, M., Flechard, C., Kuylenstierna, J., Hicks, K., Derwent, D., Johnson, C., and Stevenson, D.: The global exposure of forests to air pollutants, in: Forest Growth Responses to the Pollution Climate of the 21st Century, edited by: Sheppard, L. J. and Cape, J. N., Kluwer Academic Publisher, Dordrecht, 5-32, 1999.

Fowler, D., Amann, M., Anderson, R., Ashmore, M., Cox, P., Depledge, M., Derwent, D., Grennfelt, P., Hewitt, N., Hov, O., Jenkin, M., Kelly, F., Liss, P., Pilling, M., Pyle, J., Slingo, J., and Stefenson, D.: Ground-level ozone in the 21st century: future trends, impacts and policy implications, The Royal Society Policy Document, 132 pp., 2008.

Gamnitzer, U., Schäufele, R., and Schnyder, H.: Observing ${ }^{13} \mathrm{C}$ labelling kinetics in $\mathrm{CO}_{2}$ respired by a temperate grassland ecosystem, New Phytol., 184, 376-386, 2009.

Garten, C. T. and Taylor, G. E.: Foliar $\delta^{13} \mathrm{C}$ within a temperate deciduous forest: spatial, temporal and species sources of variation, Oecologia, 90, 1-7, 1992.

Gebhardt, T.: ${ }^{13} \mathrm{C} /{ }^{12} \mathrm{C}$-Markierung von $\mathrm{CO}_{2}$ im Boden: Methodenentwicklung und Nachweis im $\mathrm{CO}_{2}$-Efflux des Stammes an Picea abies, Diploma thesis, School of Forest Science, Ecophysiology of Plants, Department of Ecology, Technische Universität München, Freising, 81 pp., 2008.

Gessler, A., Löw, M., Heerdt, C., Op de Beeck, M., Schumacher, J., Grams, T. E. E., Bahnweg, G., Ceulemans, R., Werner, H., Matyssek, R., Rennenberg, H., and Haberer, K.: Within-canopy and ozone fumigation effects on $\delta^{13} \mathrm{C}$ and $\Delta^{18} \mathrm{O}$ in adult beech (Fagus sylvatica) trees: relation to meteorological and gas exchange parameters, Tree Physiol., 11, 1349-1365, 2009.

Gessler, A., Rennenberg, H., and Keitel, C.: Stable isotope composition of organic compounds transported in the phloem of European beech - Evaluation of different methods of phloem sap collection and assessment of gradients in carbon isotope composition during leaf-to-stem transport, Plant Biol., 6, 721-729, 2004.

Gessler, A., Tcherkez, G., Peuke, A. D., Ghashghaie, J., and Farquhar, G. D.: Experimental evidence for diel variations of the carbon isotope composition in leaf, stem and phloem sap organic matter in Ricinus communis, Plant Cell Environ., 31, 941-953, 2008.

Grams, T. E. E. and Matyssek, R.: Elevated $\mathrm{CO}_{2}$ counteracts the limitation by chronic ozone exposure on photosynthesis in Fagus sylvatica L.: comparison between chlorophyll fluorescence and leaf gas exchange, Phyton, 39, 31-40, 1999.

Grams, T. E. E., Anegg, S., Häberle, K. H., Langebartels, C., and Matyssek, R.: Interactions of chronic exposure to elevated $\mathrm{CO}_{2}$ and $\mathrm{O}_{3}$ levels in the photosynthetic light and dark reactions of European beech (Fagus sylvatica), New Phytol., 144, 95-107, 1999.

Grams, T. E. E., Kozovits, A. R., Häberle, K. H., Matyssek, R., and Dawson, T. E.: Combining $\delta^{13} \mathrm{C}$ and $\delta^{18} \mathrm{O}$ analyses to unravel competition, $\mathrm{CO}_{2}$ and $\mathrm{O}_{3}$ effects on the physiological performance of different-aged trees, Plant Cell Environ., 30, 10231034, 2007.

Grams, T. E. E., Werner, H., Kuptz, D., Ritter, W., Fleischmann, F., Andersen, C. P., and Matyssek, R.: A free-air system for longterm stable carbon isotope labeling of adult forest trees, Trees, 25, 187-198, 2011.

Grantz, D. A. and Shrestha, A.: Tropospheric ozone and 
interspecific competition between yellow nutsedge and Pima cotton, Crop Sci., 46, 1879-1889, 2006.

Grulke, N. E., Andersen, C. P., Fenn, M. E., and Miller, P. R.: Ozone exposure and nitrogen deposition lowers root biomass of ponderosa pine in the San Bernardino Mountains, California, Environ. Pollut., 103, 63-73, 1998.

Grulke, N. W., Andersen, C. P., and Hogsett, W. E.: Seasonal changes in above- and belowground carbohydrate concentration of ponderosa pine along a pollution gradient, Tree Physiol., 21, 173-181, 2001.

Günthardt-Goerg, M. S., Matyssek, R., Scheidegger, C., and Keller, T.: Differentiation and structural decline in the leaves and bark of birch (Betula pendula) under low ozone concentrations, Trees, 7, 104-114, 1993.

Högberg, P., Nordgren, A., Buchmann, N., Taylor, A. F. S., Ekblad, A., Högberg, M. N., Nyberg, G., Ottosson-Löfvenius, M., and Read, D. J.: Large-scale forest girdling shows that current photosynthesis drives soil respiration, Nature, 411, 789-792, 2001.

IPCC: Climate Change 2007: The Physical Science Basis. Contribution of Working Group I to the Fourth Assessment Report of the Intergovernmental Panel on Climate Change, edited by: Solomon, S., Qin, D., Manning, M., Chen, Z., Marquis, M., Averyt, K. B., Tignor, M., and Miller, H. L., Cambridge University Press, Cambridge, UK and New York, NY, USA, 996 pp., 2007.

Karnosky, D. F., Werner, H., Holopainen, T., Percy, K., Oksanen, T., Oksanen, E., Heerdt, C., Fabian, P., Nagy, J., Heilman, W., Cox, R., Nelson, N., and Matyssek, R.: Free-air exposure systems to scale up ozone research to mature trees, Plant Biol., 9, 181-190, 2005.

Keeling, C. D.: The concentration and isotopic abundances of atmospheric carbon dioxide in rural areas, Geochim. Cosmochim. Ac., 13, 322-334, 1958.

Keeling, C. D.: The concentration and isotopic abundance of carbon dioxide in rural and marine air, Geochim. Cosmochim. Ac., 24, 277-298, 1961.

Kitao, M., Löw, M., Heerdt, C., Grams, T. E. E., Häberle, K. H., and Matyssek, R.: Effects of chronic ozone exposure on gas exchange responses of adult beech trees (Fagus sylvatica) as related to the within-canopy light gradient, Environ. Pollut., 157, 537544, 2009.

Kozovits, A. R., Matyssek, R., Blaschke, H., Göttlein, A., and Grams, T. E. E.: Competition increasingly dominates the responsiveness of juvenile beech and spruce to elevated $\mathrm{CO}_{2}$ and/or $\mathrm{O}_{3}$ concentrations throughout two subsequent growing seasons, Glob. Change Biol., 11, 1387-1401, 2005a.

Kozovits, A. R., Matyssek, R., Winkler, J. B., Göttlein, A., Blaschke, H., and Grams, T. E. E.: Above-ground space sequestration determines competitive success in juvenile beech and spruce trees, New Phytol., 167, 181-196, 2005 b.

Kuptz, D., Fleischmann, F., Matyssek, R., and Grams, T. E. E.: Seasonal patterns of carbon allocation to respiratory pools in 60year-old deciduous (Fagus sylvatica) and evergreen (Picea abies) trees assessed via whole-tree stable carbon isotope labeling, New Phytol., 191, 160-172, 2011a.

Kuptz, D., Matyssek, R., and Grams, T. E. E.: Seasonal dynamics in the stable carbon isotope composition $\left(\delta^{13} \mathrm{C}\right)$ from non-leafy branch, trunk and coarse root $\mathrm{CO}_{2}$ efflux of adult deciduous $(\mathrm{Fa}$ gus sylvatica) and evergreen (Picea abies) trees, Plant Cell Environ., 34, 363-373, 2011 b.
Kuzyakov, Y. and Garvrichkova, O.: Time lag between photosynthesis and carbon dioxide efflux from soil: a review, Glob. Change Biol., 16, 3386-3406, 2010.

Lehmeier, C. A., Lattanzi, F. A., Schäufele, R., Wild, M., and Schnyder, H.: Root and shoot respiration of perennial ryegrass are supplied by the same substrate pools: Assessment by dynamic ${ }^{13} \mathrm{C}$ labeling and compartmental analysis of tracer kinetics, Plant Physiol., 148, 1148-1158, 2008.

LRTAP Mapping Manual: Manual on the methodologies and criteria for modelling and mapping critical loads \& levels and air pollution effects, risks and trends, UNECE, http://www.icpmapping. org., 2004.

Matyssek, R.: Carbon, water and nitrogen relations in evergreen and deciduous conifers, Tree Physiol., 2, 177-187, 1986.

Matyssek, R. and Sandermann, H.: Impact of ozone on trees: an ecophysiological perspective, Prog. Bot., 64, 349-404, 2003.

Matyssek, R., Günthardt-Goerg, M. S., Saurer, M., and Keller, T.: Seasonal growth, $\delta^{13} \mathrm{C}$ in leaves and stem, and phloem structure of birch (Betula pendula) under low ozone concentrations, Trees, 6, 69-76, 1992.

Matyssek, R., Günthardt-Goerg, M. S., Maurer, S., and Keller, T.: Nighttime exposure to ozone reduces whole-plant production in Betula pendula, Tree Physiol., 15, 159-165, 1995.

Matyssek, R., Günthardt-Goerg, M. S., Maurer, S., and Christ, R.: Tissue structure and respiration of stems of Betula pendula under contrasting ozone exposure and nutrition, Trees, 16, 375-385, 2002.

Matyssek, R., Bahnweg, G., Ceulemans, R., Fabian, P., Grill, D., Hanke, D. E., Kraigher, H., Osswald, W., Rennenberg, H., Sandermann, H., Tausz, M., and Wieser, G.: Synopsis of the CASIROZ case study: Cabon sink strength of Fagus sylvatica L. in a changing environment - Experimental risk assessment of mitigation by chronic ozone impact, Plant Biol., 9, 163-180, 2007.

Matyssek, R., Karnosky, D. F., Wieser, G., Percy, K., Oksanen, E., Grams, T. E. E., Kubiske, M., Hanke, D., and Pretzsch, H.: Advances in understanding ozone impact on forest trees: Messages from novel phytotron and free-air fumigation studies, Environ. Pollut., 158, 1990-2006, 2010a.

Matyssek, R., Wieser, G., Ceulemans, R., Rennenberg, H., Pretzsch, H., Haberer, K., Löw, M., Nunn, A. J., Werner, H., Wipfler, P., Oßwald, W., Nikolova, P., Hanke, D. E., Kraigher, H., Tausz, M., Bahnweg, G., Kitao, M., Dieler, J., Sandermann, H., Herbinger, K., Grebenc, T., Blumenröther, M., Deckmyn, G., Grams, T. E. E., Heerdt, C., Leuchner, M., Fabian, P., and Häberle, K.-H.: Enhanced ozone strongly reduces carbon sink strength of adult beech (Fagus sylvatica) - Resume from the freeair fumigation study at Kranzberg Forest, Environ. Pollut., 158, 2527-2532, 2010b.

McLaughlin, S. B., McConathy, R. K., Duwick, D., and Mann, L. K.: Effects of chronic air pollution stress on photosynthesis, carbon allocation and growth of white pine trees, Forest Sci., 28 , 60-70, 1982

Mencuccini, M. and Hölttä, T.: The significance of phloem transport for the speed with which canopy photosynthesis and belowground respiration are linked, New Phytol., 185, 189-203, 2010.

Nikolova, P. S., Andersen, C. P., Blaschke, H., Matyssek, R., and Häberle, K. H.: Belowground effects of enhanced tropospheric ozone and drought in a beech/spruce forest (Fagus sylvatica 
L./Picea abies [L.] Karst), Environ. Pollut., 158, 1071-1078, 2010.

Nunn, A. J., Kozovits, A. R., Reiter, I. M., Heerdt, C., Leuchner, M., Lütz, C., Liu, X., Löw, M., Winkler, J. B., Grams, T. E. E., Häberle, K. H., Werner, H., Fabian, P., Rennenberg, H., and Matyssek, R.: Comparison of ozone uptake and sensitivity between a phytotron study with young beech and a field experiment with adult beech (Fagus sylvatica), Environ. Pollut., 137, 494-406, 2005a.

Nunn, A. J., Reiter, I. M., Haberle, K.-H., Langebartels, C., Bahnweg, G., Pretzsch, H., Sandermann, H., and Matyssek, R.: Response patterns in adult forest trees to chronic ozone stress: identification of variations and consistencies, Environ. Pollut., 136, 365-369, 2005b.

Nunn, A. J., Wieser, G., Reiter, I. M., Häberle, K. H., Grote, R., Havranek, W. M., and Matyssek, R.: Testing the unifying theory of ozone sensitivity with mature trees of Fagus sylvatica and Picea abies, Tree Physiol., 26, 1391-1403, 2006.

Pate, J. and Arthur, D.: $\delta^{13} \mathrm{C}$ analysis of phloem sap carbon: novel means of evaluating seasonal water stress and interpreting carbon isotope signatures of foliage and trunk wood of Eucalyptus globulus, Oecologia, 117, 301-311, 1998.

Plain, C., Gerant, D., Maillard, P., Dannoura, M., Dong, Y. W., Zeller, B., Priault, P., Parent, F., and Epron, D.: Tracing of recently assimilated carbon in respiration at high temporal resolution in the field with a tuneable diode laser absorption spectrometer after in situ ${ }^{13} \mathrm{CO}_{2}$ pulse labelling of 20 -year-old beech trees, Tree Physiol., 29, 1433-1445, 2009.

Prather, M., Ehhalt, D., Dentener, F., Derwent, R., Dlugokencky, E., Holland, E., Isaksen, I., Katima, J., Kirchhoff, V., Matson, P., Midgley, P., and Wang, M.: Atmospheric Chemistry and Greenhouse Gases, in: Climate Change 2001: The Scientific Basis. Contribution of Working Group I to the Third Assessment Report of the Intergovernmental Panel on climate Change (IPCC), edited by: Houghton, J. T., Ding, Y., Griggs, D., Noguer, M., van der Linden, P., Dai, X., Maskell, K., and Johnson, C. A., Cambridge University Press, Cambridge \& New York, 239-287, 2001.

Pretzsch, H., Kahn, M., and Grote R.: The mixed spruce-beech forest stands of the "Sonderforschungsbereich" "Growth or Parasite Defence?" in the forest district Kranzberger Forst, Forstwiss. Centralbl., 117, 241-257, 1998.

Pretzsch, H., Dieler, J., Matyssek, R., and Wipfler, P.: Tree and stand growth of mature Norway spruce and European beech under long-term ozone fumigation, Environ. Pollut., 158, 10611070, 2010.

Reiling, K. and Davison, A. W.: The rsponse of ntive, hrbaceous secies to oone - Growth and fuorescence sreening, New Phytol., 120, 29-37, 1992.

Rennenberg, H., Herschbach, C., and Polle, A.: Consequences of air pollution on shoot-root interactions, J. Plant Physiol., 148, 296-301, 1996.
Ritter, W., Lehmeier, C. A., Winkler, J. B., Matyssek, R., and Grams, T. E. E.: Contrasting carbon allocation responses of juvenile European beech (Fagus sylvatica) and Norway spruce (Picea abies) to competition and ozone during late summer, in preparation, 2011.

Ryan, M. G., Hubbard, R. M., Pongracic, S., Raison, R. J., and McMurtrie, R. E.: Foliage, fine-root, woody-tissue and stand respiration in Pinus radiata in relation to nitrogen status, Tree Physiol., 16, 333-343, 1996.

Saveyn, A., Steppe, K., McGuire, M. A., Lemeur, R., and Teskey, R. O.: Stem respiration and carbon dioxide efflux of young Populus deltoides trees in relation to temperature and xylem carbon dioxide concentration, Oecologia, 154, 637-649, 2008.

Sitch, S., Cox, P. M., Collins, W. J., and Huntingford, C.: Indirect radiative forcing of climate change through ozone effects on the land-carbon sink, Nature, 448, 791-794, 2007.

Spence, R. D., Rykiel, E. J., and Sharpe, P. J. H.: Ozone alters carbon allocation in loblolly pine: assessment with carbon-11 labelling, Environ. Pollut., 64, 93-106, 1990.

Tcherkez, G., Nogues, S., Bleton, J., Cornic, G., Badeck, F., and Ghashghaie, J.: Metabolic origin of carbon isotope composition of leaf dark-respired $\mathrm{CO}_{2}$ in French bean, Plant Physiol., 131, 237-244, 2003.

Teskey, R. O., Saveyn, A., Steppe, K., and McGuire, M. A.: Origin, fate and significance of $\mathrm{CO}_{2}$ in tree stems, New Phytol., 177, 17-32, 2008.

Ubierna, N., Kumar, A. S., Cernusak, L. A., Pangle, R. E., Gag, P. J., and Marshall, J. D.: Storage and transpiration have negligible effects on $\delta^{13} \mathrm{C}$ of stem $\mathrm{CO}_{2}$ efflux in large conifer trees, Tree Physiol., 29, 1563-1574, 2009.

Vingarzan, R.: A review of surface $\mathrm{O}_{3}$ background levels and trends, Atmos. Environ., 38, 3431-3442, 2004.

Werner, H. and Fabian, P.: Free-air fumigation of mature trees - A novel system for controlled ozone enrichment in grown-up beech and spruce canopies, Environ. Sci. Pollut. R., 9, 117-121, 2002.

Wieser, G. and Matyssek, R.: Linking ozone uptake and defense towards a mechanistic risk assessment for forest trees, New Phytol., 174, 7-9, 2007.

Wieser, G., Hecke, K., Tausz, M., Häberle, K. H., Grams, T. E. E., and Matyssek, R.: The role of antioxidative defense in determining ozone sensitivity of Norway spruce (Picea abies (L.) Karst.) across tree age: Implications for the sun- and shade-crown, Phyton, 42, 245-253, 2002.

Wingate, L., Seibt, U., Maseyk, K., Ogee, J., Almeida, P., Yakir, D., Pereira, J. S., and Mencuccini, M.: Evaporation and carbonic anhydrase activity recorded in oxygen isotope signatures of net $\mathrm{CO}_{2}$ fluxes from a Mediterranean soil, Glob. Change Biol., 14, 2178-2193, 2008. 